\title{
Miron Erdei, Elemente de omiletică în preocupările teologilor români, Oradea, Editura Universității din Oradea, 2015, 254 p.
}

În anul 2015 Editura Universității din Oradea a publicat o nouă carte a părintelui Miron Erdei, ,Elemente de omiletică în preocupările teologilor români”. Sfinția sa este preot conferențiar universitar doctor habilitat la Facultatea de Teologie Ortodoxă „Episcop Dr. Vasile Coman”, paroh la

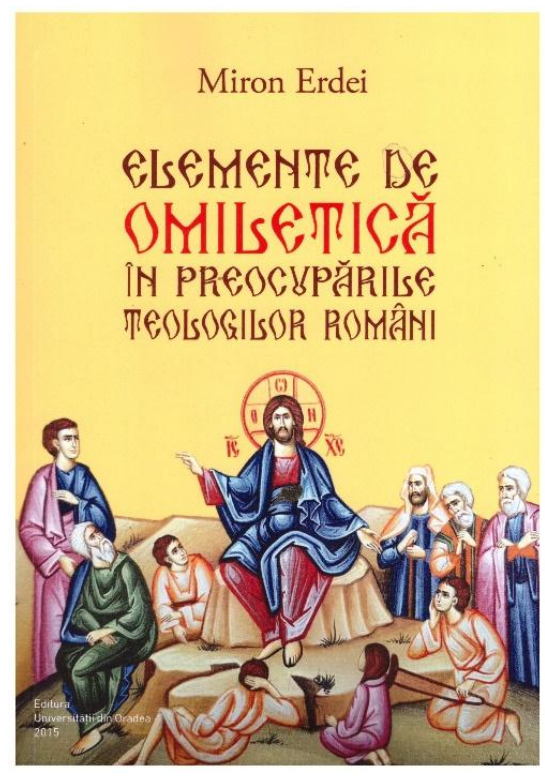

Parohia Ortodoxă Zorilor din Oradea și un familist model. Are $\mathrm{o}$ activitate publicistică bogată, cărțile și articolele sfinției sale cuprinzând valoroase informații despre propovăduirea cuvântului scripturistic în cuprinsul țării noastre, dar și din alte tărâmuri ortodoxe.

L-am întâlnit mai întâi la facultatea din Oradea, fiind unul dintre profesorii model ai studenției mele. M-a impresionat dedicarea profundă a sfinției sale pentru misiunea creștin-ortodoxă pe care și-o asumă zi de zi cu devotament, 
nu numai ca preot şi profesor, ci și ca soț şi tată în distinsa sa familie. Aceasta am simţit-o și în sfintele slujbe la care am participat alături de domnia sa, împărtășindu-și cu generozitate vasta experiență nu doar studenților ci și enoriașilor. Îmi este un model atât în activitatea de ctitor al unei noi comunități parohiale cât și al unei noi biserici cu anexele specifice, activitate pe care o continuă prin ctitorirea și a unei noi case pentru copiii orfani.

Cartea „Elemente de omiletică în preocupările teologilor români" este structurată pe șapte capitole, conținutul ei întinzânduse pe parcursul a 254 de pagini. În cuprinsul ei găsim o impresionantă bibliografie de 2750 de cărți și articole scrise de ierarhi ortodocși români, profesori,preoți, diaconi, teologi șilaici lucrări publicate între anii 1847 - 2015.

După „Prefaţă” și „Abrevieri”, primul capitol, intitulat „Manuale de Omiletică, cărți de specialitate și lucrări cu caracter omiletic" ne prezintă 207 de cărți scrise de 102 autori. Capitolul al doilea conține 28 de teze de doctorat cu conținut omiletic, iar în capitolul al treilea descoperim că până în anul 2015 s-au publicat 433 de volume de predici elaborate de 213 autori. Apăruseră tot până în același an 26 de broșuri de predici și cuvântări ocazionale scrise de 6 teologi, iar în capitolul al cincilea găsim 79 de colecții de meditații ale celor 40 de autori. În capitolul al șaselea sunt enumerate 34 de colecții de pilde și povestiri religioase adunate în pagini de carte de 19 scriitori şi o colecție de pilde pentru copii, având autor necunoscut.

Capitolul al șaptelea este cel mai amplu, el ocupând mai mult de jumătate din carte, în cele 68 de subcapitole regăsindu-se 1943 de studii cu caracter omiletic, publicate de numeroşi autori în revistele de teologie din cuprinsul Patriarhiei Ortodoxe Române, în culegeri de studii, antologii, volume omagiale șivolume colective.

Cartea „Elemente de omiletică în preocupările teologilor români" este un rod al muncii de aproape 35 de ani de studiu al teologiei ortodoxe. Este un dar al părintelui profesor Miron Erdei pentru omul, teologul, sau specialistul care are nevoie de informaţii despre transmiterea cuvântului scripturistic, ,apa cea vie" pe care Dumnezeu ne-a lăsat-o nu doar pentru ca omul să nu moară, ci mai 
mult, pentru ca omul să crească în asemănarea cu Tatăl său ceresc. $\mathrm{Cu}$ recunoștință pentru acest rod al muncii părintelui profesor împărtășesc afirmația sfinției sale: „,faptul că predica Mântuitorului lisus Hristos, a Sfinţilor Apostoli şi a urmaşilor acestora a avut şi are rezonanţă în inimile ascultătorilor se datorează, incontestabil, unei propovăduiri ordonate, cu un scop precis şi cu un conţinut accesibil, plin de sevă divină, ţinând cont şi de structura spirituală a ascultătorilor", în acest sens cartea sa fiind de un real ajutor.

\section{Pr. drd. Felix BICĂZAN}

Facultatea de Teologie Ortodoxă „Episcop Dr. Vasile Coman” Universitatea din Oradea 